\title{
Comparison of Microtox and Xenoassay Light as a Near Real Time River Monitoring Assay for Heavy Metals
}

\author{
M. I. E. Halmi, ${ }^{1}$ Hussain Jirangon, ${ }^{1}$ W. L. W. Johari, ${ }^{2,3}$ A. R. Abdul Rachman, ${ }^{1}$ \\ M. Y. Shukor, ${ }^{1}$ and M. A. Syed ${ }^{1}$ \\ ${ }^{1}$ Department of Biochemistry, Faculty of Biotechnology and Biomolecular Sciences, Universiti Putra Malaysia, UPM Serdang, \\ 43400 Selangor, Malaysia \\ ${ }^{2}$ Department of Environmental Science, Faculty of Environmental Studies, Universiti Putra Malaysia, UPM Serdang, \\ 43400 Selangor, Malaysia \\ ${ }^{3}$ Centre of Excellence for Environmental Forensics, Universiti Putra Malaysia, UPM Serdang, 43400 Selangor, Malaysia
}

Correspondence should be addressed to M. Y. Shukor; mohdyunus@upm.edu.my

Received 21 December 2013; Accepted 23 February 2014; Published 1 April 2014

Academic Editors: A. Geng and J. Yoon

Copyright (C) 2014 M. I. E. Halmi et al. This is an open access article distributed under the Creative Commons Attribution License, which permits unrestricted use, distribution, and reproduction in any medium, provided the original work is properly cited.

Luminescence-based assays for toxicants such as Microtox, ToxAlert, and Biotox have been used extensively worldwide. However, the use of these assays in near real time conditions is limited due to nonoptimal assay temperature for the tropical climate. An isolate that exhibits a high luminescence activity in a broad range of temperatures was successfully isolated from the mackerel, Rastrelliger kanagurta. This isolate was tentatively identified as Photobacterium sp. strain MIE, based on partial 16S rDNA molecular phylogeny. Optimum conditions that support high bioluminescence activity occurred between 24 and $30^{\circ} \mathrm{C}$, with pH 5.5 to $7.5,10$ to $20 \mathrm{~g} / \mathrm{L}$ of sodium chloride, 30 to $50 \mathrm{~g} / \mathrm{L}$ of tryptone, and $4 \mathrm{~g} / \mathrm{L}$ of glycerol as the carbon source. Assessment of near real time capability of this bacterial system, Xenoassay light to monitor heavy metals from a contaminated river running through the Juru River Basin shows near real time capability with assaying time of less than 30 minutes per samples. Samples returned to the lab were tested with a standard Microtox assay using Vibrio fishceri. Similar results were obtained to Xenoassay light that show temporal variation of copper concentration. Thus, this strain is suitable for near real time river monitoring of toxicants especially in the tropics.

\section{Introduction}

The extensive industrial and agricultural activities in Malaysia have resulted in the increase of pollutants such as heavy metals, pesticides, and organic and inorganic solvents in the environment. Malaysian Department of Environment (DOE) in 2011 has categorized 189 out of 464 rivers as polluted or slightly polluted [1], which is an issue of concern due to the toxicity, carcinogenicity, and mutagenicity of the pollutants. Toxicants can cause potentially harmful effects to human beings, aquatic organisms, and food webs because some of them cannot be fully degraded [2]. Toxicants, especially heavy metals, are toxic to aquatic organisms. Therefore, it is important to periodically monitor toxicants in the environment [3]. A simple and fast procedure is required to screen for the presence of toxic substances from industrial effluents, polluted rivers, and other polluted locations $[4,5]$.

Bioluminescence-based systems are suitable for preliminary screening of toxicants in the environment. This system is sensitive to many toxicants and utilizes a rapid and simple operation [6]. Despite its simplicity, it can represent the real impact of all chemicals present in a given sample or ecosystems [7]. The system involves bioluminescent bacteria, which are widely distributed in marine, freshwater, and terrestrial environment [8]. Bioluminescence is an aerobic oxidation process and the enzyme involved in the production of luminescence is luciferase. The enzyme catalyzes the oxidation of its substrate, luciferin, and is mediated by a reduced coenzyme, flavin mononucleotide. The interactions of toxicants with the bioluminescent bacteria cause the 
inhibition of the luminescence production [7]. The effect of toxicants on the microorganisms can be determined within 30 minutes or less depending on the types of toxicants [9]. An example of a commercially produced bioassay using bioluminescent bacterial cultures is the Microtox system [10]. This system uses the bacterium Vibrio fischeri and has an optimal assay temperature of $15^{\circ} \mathrm{C}[11,12]$. Deviations of a few degrees Celsius from this temperature can dramatically affect the luminescence production [13]. The system requires a refrigerated water bath, which is not practical, expensive to maintain, and instrument-dependent for field applications in the tropical regions [14]. A tropical country such as Malaysia can exhibit a wide variation of daily temperatures ranging from 23 at night to $34^{\circ} \mathrm{C}$ in the afternoon [15]. Other commercial bioluminescence-based systems such as ToxAlert also require an exact assay temperature at $15^{\circ} \mathrm{C}$ and Biotox as well as Toxi-Screening Kit is stable between 15 and $25^{\circ} \mathrm{C}$ [13]. Thus, a tropical bioluminescent bacterium that could cover this broad tropical temperature range is urgently needed.

In this work, we have isolated Photobacterium sp. strain MIE from mackerel (Rastrelliger kanagurta) from the local market. The tropical isolate is capable of high luminescent activity within a broad range of temperature from $24^{\circ} \mathrm{C}$ to $30^{\circ} \mathrm{C}$. This study aims to characterize the optimum conditions for growth and the environmental factors that are essential for bioluminescence production. A field trial has been conducted on Malaysian water to demonstrate the near real time application of this bacterium.

\section{Materials and Methods}

2.1. Chemicals. All chemicals used were of analytical grade and purchased either from Sigma (St. Louis, MO, USA), Fermentas (USA), Merck (Darmstadt, Germany), or Qiagen (Valencia, CA, USA).

2.2. Isolation and Screening of Bioluminescent Bacteria. The bioluminescent bacteria were screened from different marine organisms and sea waters. Marine organisms such as sardines, mackerel, squids, and prawn were bought from the Sri Serdang Market, Selangor, in November 2010. Seawater was collected from Port Dickson, Negeri Sembilan, and Kuala Juru, Pulai Pinang, in December 2010. The marine organisms were half-submerged in $3 \%(\mathrm{w} / \mathrm{v})$ of $\mathrm{NaCl}$ solution for 24 hours at $20^{\circ} \mathrm{C}$. After 24 hours of incubation, $1 \mathrm{~mL}$ from each sample was diluted 10 times and $50 \mu \mathrm{L}$ was spread on luminescence agar containing the following (per L): $10 \mathrm{~g}$ $\mathrm{NaCl}, 10 \mathrm{~g}$ peptone, $3 \mathrm{~mL}$ glycerol, $3 \mathrm{~g}$ yeast extract, and $18 \mathrm{~g}$ agar. The plates were incubated at room temperature $\left(27^{\circ} \mathrm{C}\right)$ for 24 hours until the bacterial colonies were visible $[9,16,17]$. For screening purpose, a single colony was inoculated into $200 \mathrm{~mL}$ conical flask containing $50 \mathrm{~mL}$ of the luminescent broth and incubated at $100 \mathrm{rpm}$ on a rotary shaker for 12 hours at room temperature.

2.3. Identification of Bacterium. Identification of strain MIE was done by using several tests mainly on the basis of its cultural and morphological characteristics (micro- and macromorphological features) on the nutrient agar, gram staining, and followed by sequence analysis of $16 \mathrm{~S}$ ribosomal RNA. 16S rRNA analysis provides a powerful phylogenetic framework for classification of organisms [18]. Genomic DNA extraction was performed by alkaline lysis using DNeasy Blood \& Tissue Purification Kit (Qiagen, USA). 16S rRNA genes were amplified by using genomic DNA and universal primer pair $\left(5^{\prime}\right.$-AGAGTTTGATCATGGCTGAG$3^{\prime}$ and $5^{\prime}$-ACGGTTACCTTGTTACGACTT- $3^{\prime}$ ). The amplicons were purified prior to sequencing. The resultant bases were compared with the GenBank database using the Blast server at NCBI (http://www.ncbi.nlm.nih.gov/BLAST/). The 16s rRNA ribosomal gene sequence was deposited in GenBank under Accession number JX020946.

2.4. Phylogenetic Analysis. A multiple alignments of 19 different $16 \mathrm{~S}$ rRNA gene sequences, which closely match strain MIE, were retrieved from GenBank and aligned using clustal W [19] with the PHYLIP output option. The alignment was checked by eye for any obvious misalignments. Alignment positions with gaps were excluded from the calculations. A phylogenetic tree was constructed by using PHYLIP, version 3.573 (J. Q. Felsenstein, PHYLIP-phylogeny inference package, version 3.573, (http://evolution.genetics.washington.edu/phylip.html)), with Rhodococcus sp. YB1 as the outgroup in the cladogram. The four models of nucleotide substitution are those of [20-22], the F84 model [23], and the model underlying the Log Det distance [24]. Phylogenetic tree was inferred by using the neighbor-joining method [25]. With each algorithm, confidence levels for individual branches within the tree were checked by repeating the PHYLIP analysis with 1000 bootstraps [26] by the SEQBOOT program in the PHYLIP package. Majority rule (50\%) consensus trees were constructed for the topologies found using a family of consensus tree methods called the $\mathrm{Ml}$ methods using the CONSENSE program and the tree was viewed using Tree View [27].

2.5. Characterization of Bioluminescence Production of Isolated Bioluminescent Bacterium. It is important to investigate the best condition for the selected isolate to produce an optimum and stable luminescence [28]. The bacterial cultures were tested on different types of carbon and nitrogen sources, in addition to wide ranges of $\mathrm{NaCl}$ concentrations, $\mathrm{pHs}$, and temperatures.

2.6. Measurement of Luminescence. Luminescence was measured using a Beckman Counter DTX 800 multimode detector and reported as Relative Luminescence Unit (RLU). $200 \mu \mathrm{L}$ of samples was collected in DTX microplate 96 wells before the readings were taken. The measurements were taken in triplicate.

2.7. Identification of Responsible Luciferase Gene by Specific PCR. The total genomic DNA of Photobacterium strain MIE was extracted by using Thermo Genomic kit and used as 
template for polymerase chain reaction (PCR) for detection of the presence luciferase gene in Photobacterium strain MIE genomic. PCR assay was performed in $12.5 \mu \mathrm{L}$ reaction mixture, containing $1 \mu \mathrm{L}$ genomic DNA solution, $2 \mathrm{U}$ of Taq polymerase (Bioline, London, U.K), 1X MyFi reaction buffer including dNTP's, $\mathrm{MgCl}_{2}$ and enhancer (Bioline, London, U.K), and 20 pmol for each specific primer (Firstbase, Malaysia).

Amplification reaction was performed by using Biorad thermocycler (Biorad). First step is initial denaturation that was applied for $1 \mathrm{~min}$ at $95^{\circ} \mathrm{C}$. After that, 30 cycles were performed, consisting of $15 \mathrm{~s}$ denaturation at $95^{\circ} \mathrm{C}, 15 \mathrm{~s}$ annealing at $55^{\circ} \mathrm{C}$, and $90 \mathrm{~s}$ extension at $72^{\circ} \mathrm{C}$, followed by $7 \mathrm{~min}$ final extension at $72^{\circ} \mathrm{C}$ and cooling at $10^{\circ} \mathrm{C}$. The PCR mixture was viewed using $1 \%$ agarose gel electrophoresis by using $1 \mathrm{~kb}$ DNA ladder mixture marker (Fermentas).

2.8. Near Real-Time Biomonitoring Field Trials. The bioluminescent bacterium Photobacterium sp. strain MIE was cultured in luminescence broth for 12 hours at room temperature. After a 12-hour incubation, the bacterial cell was harvested by centrifugation $(10000 \times \mathrm{g}, 10 \mathrm{~min})$ and the pellet was diluted using minimal salt media (MSM) ( $1 \mathrm{~L}$ of distilled water was supplemented with $12.8 \mathrm{~g} \mathrm{Na} \mathrm{HPO}_{4} \cdot 7 \mathrm{H}_{2} \mathrm{O}, 3.1 \mathrm{~g}$ $\mathrm{KH}_{2} \mathrm{PO}_{4}, 17 \mathrm{~g} \mathrm{NaCl}, 1 \mathrm{~g} \mathrm{NH} \mathrm{NH}_{4} \mathrm{Cl} 0.5 \mathrm{~g} \mathrm{MgSO}_{4}$, and $3 \mathrm{~mL}$ glycerol), which has been used as substitute media for toxicity assay [29]. High density of bacterial culture can also affect the sensitivity and luminescence of the bioassay. The culture was further diluted 1000 times so that the emission was within the range of 50,000 to 100,000 RLU prior to assaying [9]. The assay was conducted by mixing $20 \mu \mathrm{L}$ of water samples with $180 \mu \mathrm{L}$ of bacterial cultures. One location was selected and used to demonstrate near real time applicability of the developed assay. Water samples were obtained every two hours for a period of one day from a large drain at the Prai Industrial Park ( $05^{\circ} 20.87^{\prime}$ E $\left.100^{\circ} 24.692^{\prime}\right)$. This area was chosen as it was previously reported with high concentrations of heavy metals $[4,30]$. The total time per assay was approximately 30 minutes and luminescence was measured with a portable luminometer (MicroBioTests Inc., Mariakerke (Gent, Belgium)).

2.9. Microtox Toxicity Assay. The assay method of Microtox was carried out by following the recommended procedure as suggested by the manufacturer with minor modification. Briefly, $1 \mathrm{~mL}$ of chilled distilled water was added into a vial of freeze-dried Photobacterium phosphoreum cells (Arachem Sdn. Bhd) and slowly mixed by swirling the vial to reconstitute the cells. The cells must be used within a few hours. Quality control of the assay performance can be validated using a phenol standard solution $(10 \mathrm{mg} / \mathrm{L})$. Appropriately diluted samples were prepared in $2 \%$ sodium chloride solution and about $10^{6}$ cells were added to the dilution vials. An emission of between the range of 20,000 and 40,000 RLU was obtained. Measurement of luminescence (Beckman Counter DTX 800 multimode detector) at time zero and after $30 \mathrm{~min}$ was carried out and compared to control solution (sodium chloride 2\%) minus the tested compound. All the assay and dilution operations were carried out at $15 \pm 0.5^{\circ} \mathrm{C}$ [31].

2.10. Determination of Heavy Metals. The determination of heavy metals in the samples was carried out using atomic emission spectrometry on ICP-OES (Optima 3700DV, Perkin-Elmer, USA). All experiments were performed in triplicate.

2.11. Statistical Analysis. All data were analyzed using Graphpad Prism version 5.0. Values are means \pm standard errors. The comparison between groups was performed using a Student's $t$-test or a one-way analysis of variance with posthoc analysis by Tukey's test. $P<0.05$ was considered statistically significant.

\section{Results}

3.1. Isolation, Screening, and Identification of Bioluminescent Bacteria. In this study, isolates were chosen based on the ability to produce strong luminescence at room temperature $\left(27^{\circ} \mathrm{C}\right)$. Among the 15 luminescent isolates, only isolate $\mathrm{K} 10$ (isolated from mackerel) was able to grow in the luminescence media with good intensity of blue-green light after 12 hours of incubation period at room temperature (data not shown). Isolate K10 was found to be a gram-negative and rodshaped bacterium. Through $16 \mathrm{~S}$ rRNA sequence analysis, a low bootstrap value (22.3\%) links isolate K10 to P. kishitanii strain vlong 1.3, indicating a low phylogenetic relationship (Figure 1). This bacterium is grouped with Photobacterium species, albeit in a separate branch, which conversely have low bootstrap values $(<50 \%)$, implying that its phylogenetic position might still be modified. This bacterium is assigned tentatively as Photobacterium sp. strain MIE with Accession number of JX020946.

\subsection{Characterization of Bioluminescence Production}

3.2.1. Effect of Carbon Sources. Carbon source was an important luminescence parameter to this bacterium as luminescence activity was not observed in the medium without carbon source (Figure 2). Out of the nine carbon sources tested, only glycerol produced the highest significant $(P<$ 0.05 ) luminescence while there was no significant difference in terms of bioluminescence production for starch and dextrin $(P>0.05)$. Other carbon sources such as D-raffinose, galactose, maltose, and glucose showed bioluminescence production but at much lower levels. The effect of different concentrations of glycerol on luminescence production showed that the optimum concentration of glycerol was $4 \mathrm{~g} / \mathrm{L}$ $(P<0.05)$ after 12 hours of incubation period (Figure 3$)$.

3.2.2. Effect of Nitrogen Source. High emission of luminescence was observed when the culture was grown with either peptone or tryptone (Figure 4) but tryptone gave a significantly higher $(P<0.05)$ luminescence than peptone. Other nitrogen sources tested did not support luminescence 


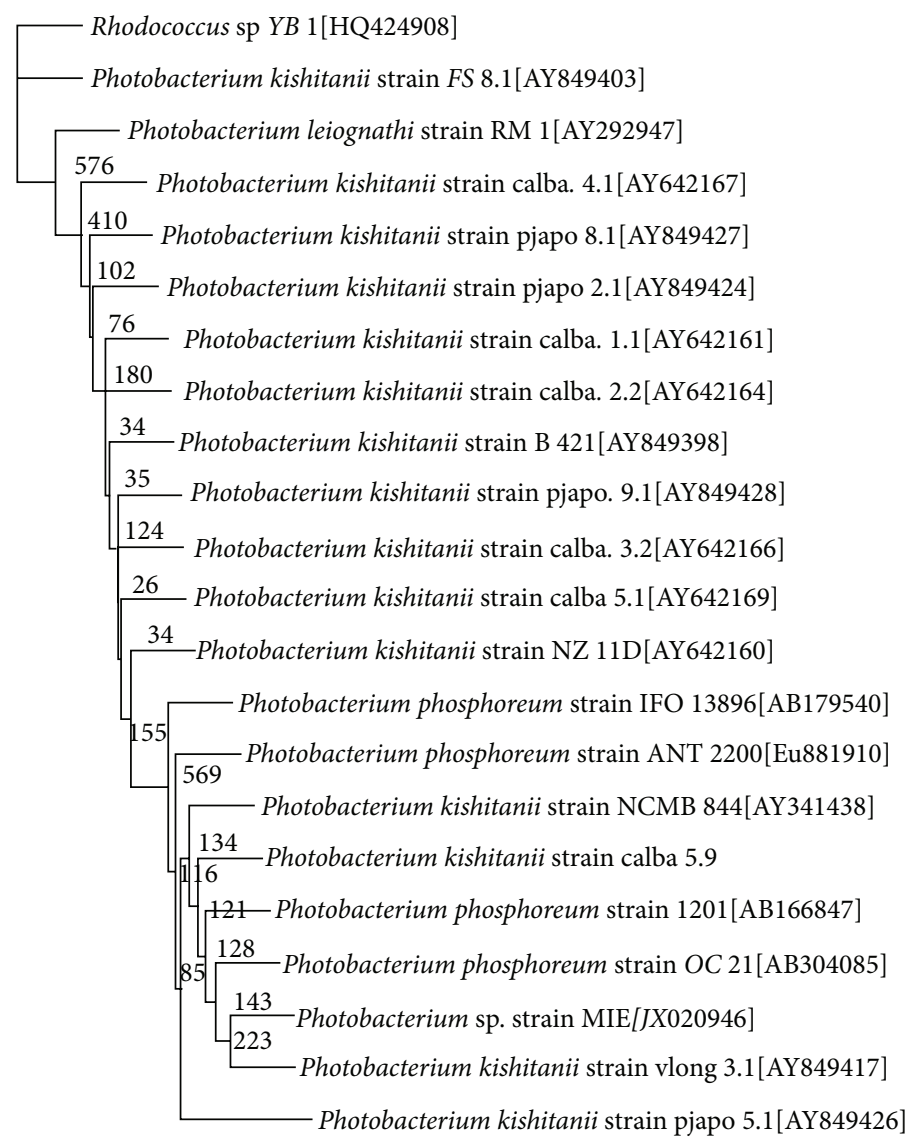

FIgURE 1: Phylogram (neighbour-joining method) showing the genetic relationship between Photobacterium sp. strain MIE and other related references microorganisms based on the 16S rRNA gene sequence analysis from the GenBank database. Rhodococcus sp. is the outgroup. Species names were followed by the accession numbers of $16 \mathrm{~S}$ rRNA. The internal labels at the branching points refer to bootstrap value. Scale bar represents 100 nucleotides substitution.

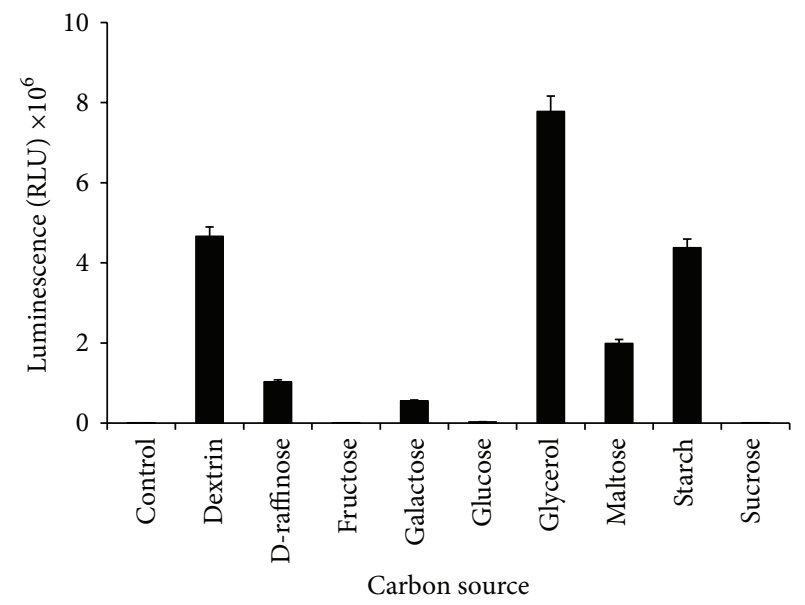

FIGURE 2: Effects of different carbon sources on bioluminescence production of Photobacterium sp. strain MIE. The isolate was grown in luminescence media containing $1 \mathrm{~g} / \mathrm{L}$ of carbon sources incubated in orbital shaker $(100 \mathrm{rpm})$ for 12 hours at room temperature. Data is mean \pm standard error of the mean $(n=3)$. The cultures were grown without any carbon source as control.

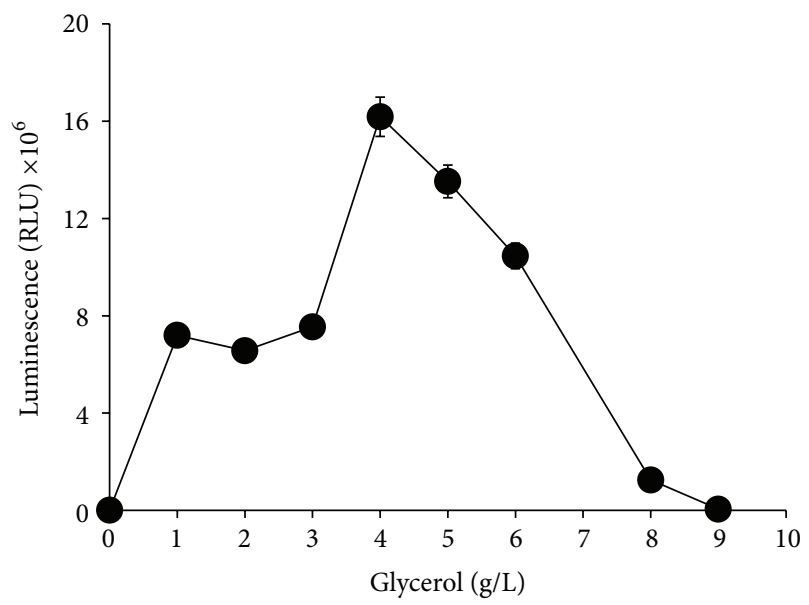

FIGURE 3: Effects of glycerol concentration on bioluminescence production of Photobacterium sp. strain MIE. The cultures were grown in luminescence media containing different concentration of glycerol incubated in orbital shaker $(100 \mathrm{rpm})$ for 12 hours at room temperature. Data is mean \pm standard error of the mean $(n=3)$. 


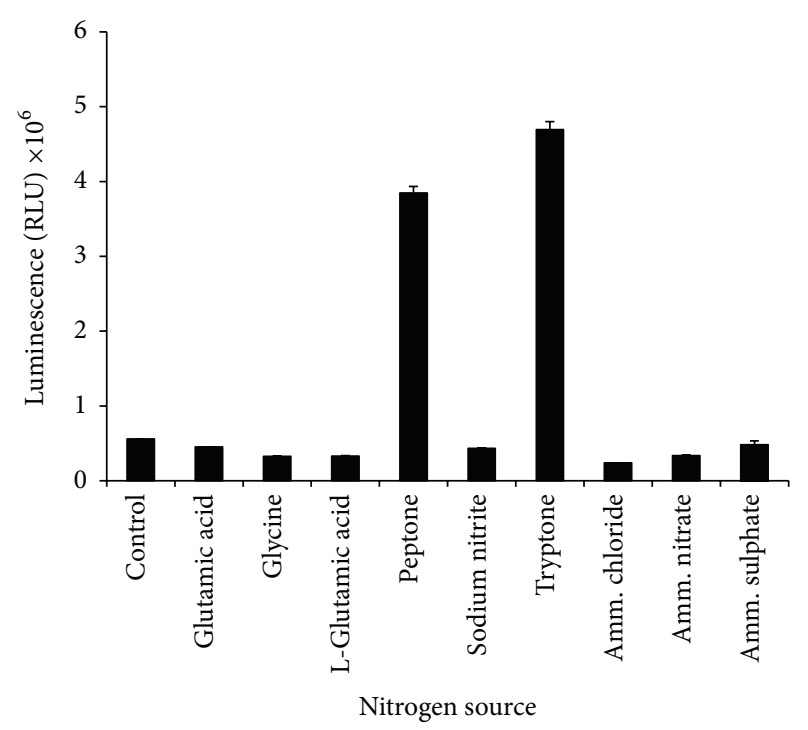

FIGURE 4: Effects of different nitrogen sources on bioluminescence production by Photobacterium sp. strain MIE. The cultures were grown in luminescence media containing $10 \mathrm{~g} / \mathrm{L}$ nitrogen sources and incubated in an orbital shaker $(100 \mathrm{rpm})$ for 12 hours at room temperature. Data is mean \pm standard error of the mean $(n=3)$. The cultures were grown without nitrogen source as control.

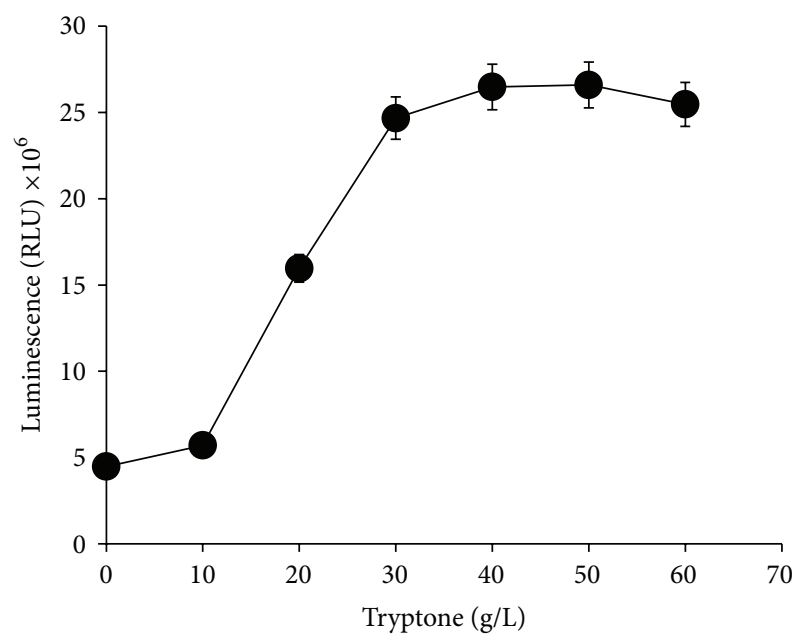

FIGURE 5: Effects of different tryptone concentrations on bioluminescence production of Photobacterium sp. strain MIE. The cultures were grown in luminescence media containing different concentrations of tryptone and incubated in an orbital shaker $(100 \mathrm{rpm})$ for 12 hours at room temperature. Data is mean \pm standard error of the mean $(n=3)$.

activity in this bacterium. The optimum concentration of tryptone was between 30 and $40 \mathrm{~g} / \mathrm{L}$ (Figure 5).

3.2.3. Effect of Salinity. The concentration of sodium chloride required to produce high luminescence activity was between 10 and $20 \mathrm{~g} / \mathrm{L}$ with no significant difference $(P>0.05)$ between the values obtained after 12 hours incubation time

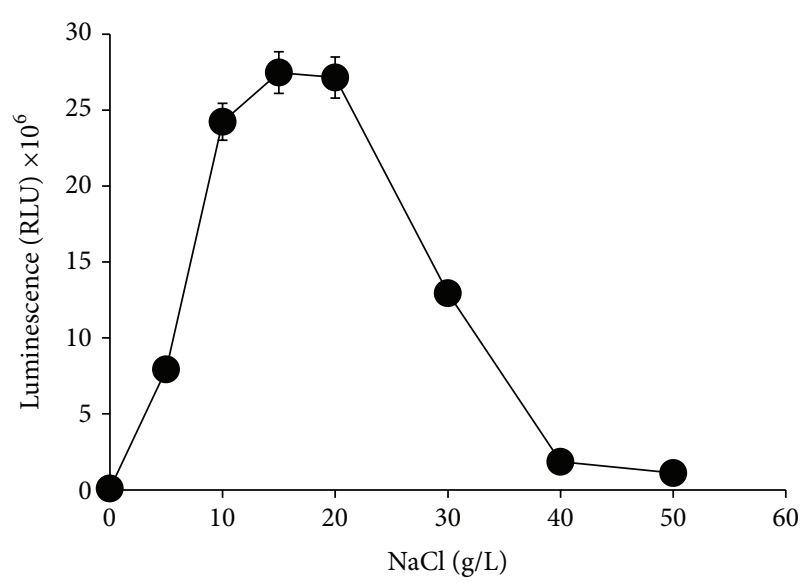

FIGURE 6: Effects of sodium chloride on bioluminescence production by Photobacterium sp. strain MIE. The cultures were grown in luminescence media containing different concentrations of sodium chloride and incubated in an orbital shaker $(100 \mathrm{rpm})$ for 12 hours at room temperature. Data is mean \pm standard error of the mean $(n=3)$.

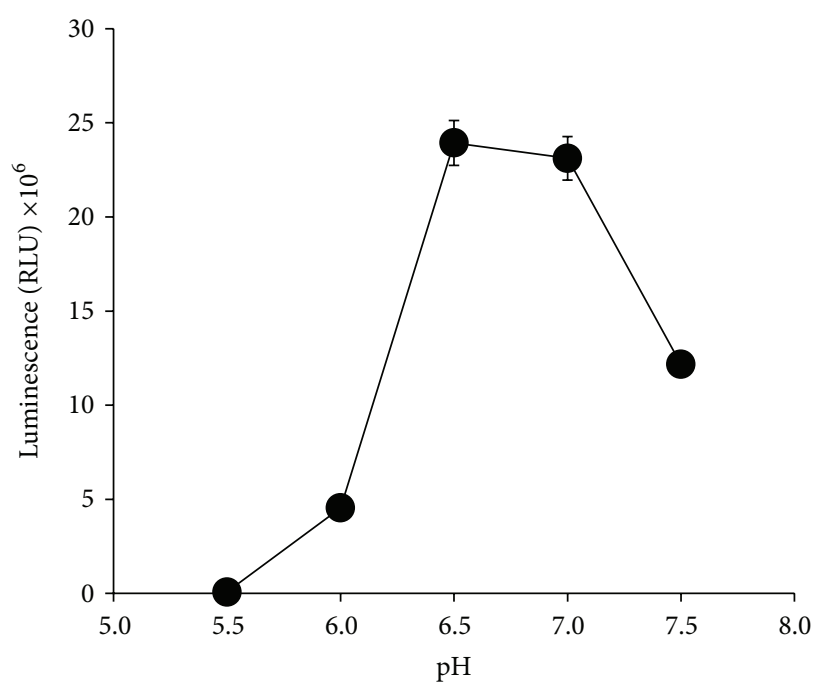

FIGURE 7: Effects of different $\mathrm{pHs}$ on bioluminescence production by Photobacterium sp. strain MIE in luminescence media. The isolate was grown in luminescence media at different $\mathrm{pH}$ and incubated in an orbital shaker $(100 \mathrm{rpm})$ for 12 hours at room temperature. Data is mean \pm standard error of the mean $(n=3)$.

in luminescence media. Luminescence activities dramatically dropped below and above this range (Figure 6).

3.2.4. Effect of $\mathrm{pH}$. This bacterium was able to produce high luminescence at $\mathrm{pH}$ between 5.5 and 7.5 with no significant difference $(P>0.05)$ between the $\mathrm{pH}$ values after 12 hours incubation time in luminescence media. Luminescence production of the bacterium ceased completely outside of this range (Figure 7). 


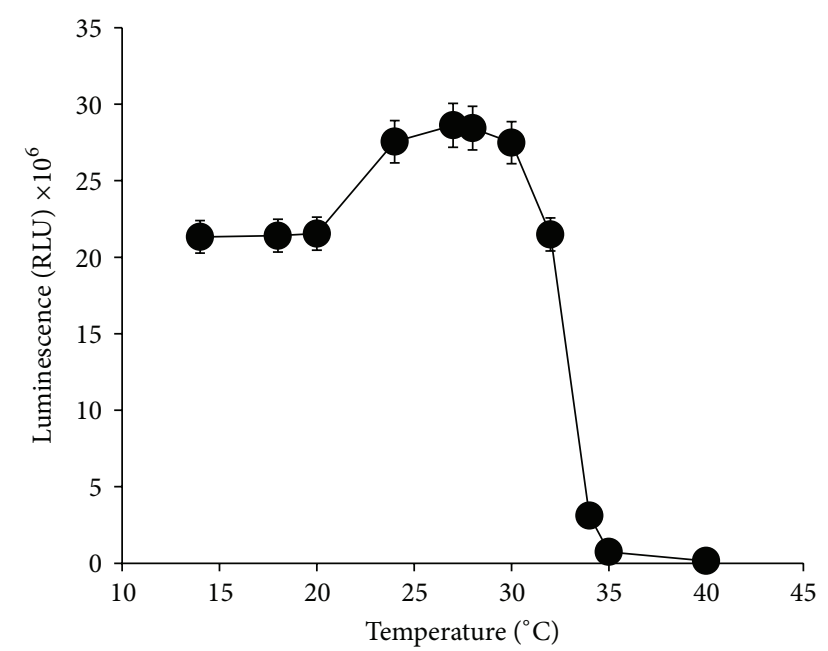

FIGURE 8: Effects of different temperatures on bioluminescence produced by Photobacterium sp. strain MIE. The cultures were grown in luminescence media at different temperatures and incubated in an orbital shaker $(100 \mathrm{rpm})$ for 12 hours. Data is mean \pm standard error of the mean $(n=3)$.

3.2.5. Effect of Temperature. Stable production of bioluminescence was observed between 24 and $30^{\circ} \mathrm{C}$ with no significant differences $(P>0.05)$ between the temperatures. At temperatures lower than this range especially between 15 and $20^{\circ} \mathrm{C}$, luminescence fell to about $75 \%$ of optimal value while at temperatures higher than the optimal values, luminescence ceased completely (Figure 8).

3.2.6. Profile of Bioluminescence Production and Bacterial Growth. In order to determine the overall maximum bioluminescence production, Photobacterium sp. strain MIE was grown under the optimal conditions as described in the previous sections. The growth and luminescence curves of this bacterium are presented in Figure 9. The absorbance value was correlated with the bacterial number which represents bacterial growth. The luminescence was correlated with bacterial number and luminescent efficiency. The results show that the luminescence peak corresponds to bacterial growth and the luminescence production started to increase during the logarithmic growth phase. Luminescence only appeared after 8 hours of incubation. The bacterial cultures produced peak luminescence between 12 and 24 hours of incubation and started to decline above 24 hours (Figure 9). The bioluminescence of Photobacterium sp. strain MIE grown in shake flask taken in the dark is shown in Figure 10.

3.3. Isolation and Sequencing of Luciferase Gene. Luciferase genes were successfully amplified using luciferase-specific primers. The expected size of luciferase nucleotide sequence was approximately $2.1 \mathrm{kbp}$. New isolated luciferase genes from Photobacterium strain MIE consisted of alpha and beta subunits. Based on Figure 11, alpha and beta subunits of the luciferase gene contained 1071 nucleotide sequences encoding 356 amino acids, and 984 nucleotide sequences encoding 327 amino acids, respectively, (Figure 11). Sequence of the full

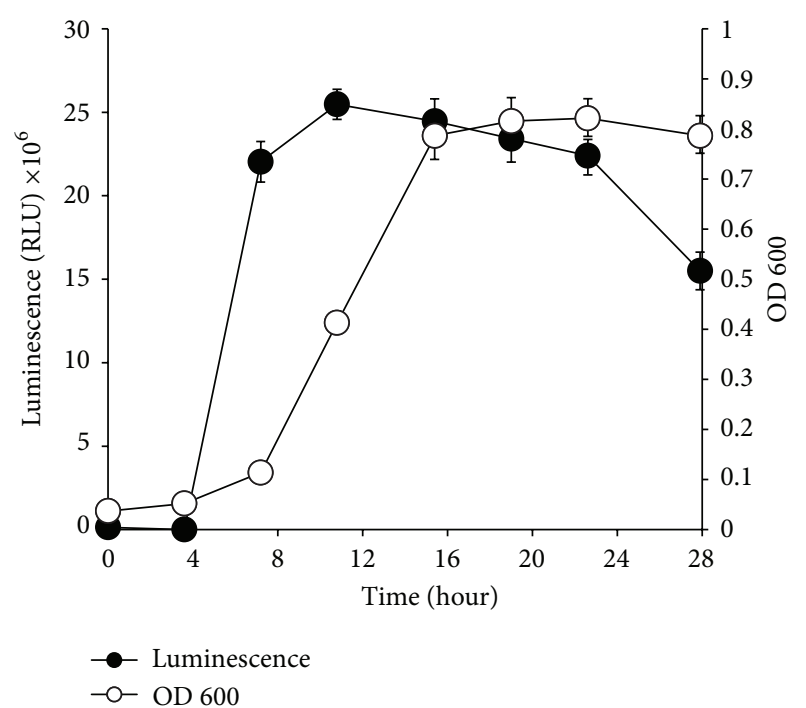

FIGURE 9: Bioluminescence production and bacterial growth of Photobacterium sp. strain MIE in luminescence media over time. The isolate was grown in luminescence media and incubated in an orbital shaker (100 rpm) for 28 hours at room temperature. Bioluminescence production (black circle) and bacterial growth (circle) were determined using Beckman Counter DTX 800 multimode detector. The error bars represent the mean \pm standard deviation of three replicates.

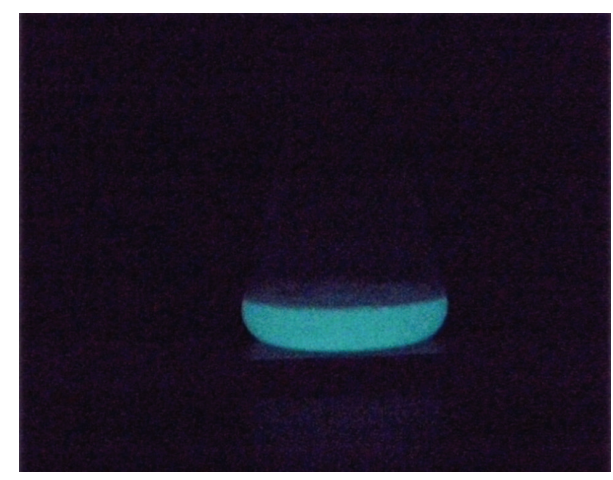

FIGURE 10: The bacterial cultures produced luminescence in dark condition when grown in luminescence broth for 12 hours at room temperature $\left(27^{\circ} \mathrm{C}\right)$.

length luciferase gene was generated by nucleotide sequencer machine (First Base, Malaysia). The luciferase gene was represented by alpha subunit luciferase (Lux A) and the beta subunit luciferase (Lux B). Figure 11 indicates the positions of lux $\mathrm{A}$ and lux $\mathrm{B}$ genes in the luciferase nucleotide sequence. The sequence of the luciferase gene has been deposited in GenBank (Accession no. KF926858).

3.4. Near Real Time Field Trial. A time-of-the-day profile of the copper concentration in water samples of an industrial drain in the Juru Industrial Park flown into the Juru River Basin showed similar temporal inhibition between the candidate bacterial and the Microtox assays. Close correlation with inhibition of bioluminescence activity in both assays 
atgaagtttggaaatattttctcatatcagcctccaggtgagtcacataaagaagtcatg \begin{tabular}{llllllllllllllllllll}
\hline & K & $F$ & $G$ & $N$ & $I$ & $F$ & $S$ & $Y$ & $Q$ & $P$ & $P$ & $G$ & $E$ & $S$ & $H$ & $K$ & $E$ & $V$ & $M$
\end{tabular} gatcgctttgttcgtttaggcgttgcatcagaagaactaaattttgatacttactggact

$\begin{array}{llllllllllllllllllll}D & R & F & V & R & L & G & V & A & S & E & E & L & N & F & D & T & Y & W & T\end{array}$ ctagagcatcattttactgaatttggactaacaggtaacctgtatgttgcttgtgctaac

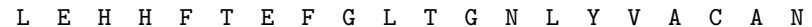
ttacttggtcgaaccaccaaactgaatgttggtactatgggtattgttcttccaacagct $\begin{array}{llllllllllllllllllll}\mathrm{L} & \mathrm{L} & \mathrm{G} & \mathrm{R} & \mathrm{T} & \mathrm{T} & \mathrm{K} & \mathrm{L} & \mathrm{N} & \mathrm{V} & \mathrm{G} & \mathrm{T} & \mathrm{M} & \mathrm{G} & \mathrm{I} & \mathrm{V} & \mathrm{L} & \mathrm{P} & \mathrm{T} & \mathrm{A}\end{array}$ cacctgcacgtcagatggaagatttattacttttagatcaaatgtcaaaaggacgtttt $\begin{array}{llllllllllllllllllll}H & P & A & R & Q & M & E & D & L & L & L & L & D & Q & M & S & K & G & R & F\end{array}$ aattttggtgttgtgcgtggcttgtaccacaaagatttccgcgtttttggtgtaacgatg $\begin{array}{llllllllllllllllllll}N & F & G & V & V & R & G & L & Y & H & K & D & F & R & V & F & G & V & T & M\end{array}$ gaagattctcgtgctatcactgaagattttcataccatgattatggatggtacaaaaca $\begin{array}{lllllllllllllllllllll}E & D & S & R & A & I & T & E & D & F & H & T & M & I & M & D & G & T & K & T\end{array}$ ggtacacttcatactgatggtaaaacatcgaattcccagatgtaaacgtttacccagag $\begin{array}{llllllllllllllllllll}\text { G } & \text { T } & \text { L } & \text { H } & \text { T } & \text { D } & G & \text { K } & \text { N } & \text { I } & \text { E } & \text { F } & \text { P } & \text { D } & \text { V } & \text { N } & \text { V } & \text { Y } & \text { P } & \text { E }\end{array}$ gcgtatttagagaaaattccaacatgcatgactgctgaatcagcagtaacaacgacttgg $\begin{array}{llllllllllllllllllll}A & Y & L & E & K & I & P & T & C & M & T & A & E & S & A & V & T & T & T & W\end{array}$ cttgctgagcgtggcttaccgatggttcttagttggattattacaacgagtgaaaagaaa $\begin{array}{llllllllllllllllllll}\text { L } & A & E & R & G & L & P & M & \text { V } & \text { L } & \text { S } & \text { W } & \text { I } & \text { I } & \text { T } & \text { T } & \text { S } & \text { E } & \text { K } & \text { K }\end{array}$ gctcaaatggaactctataatgctgttgctcgagatagcggttacagtgaagagtacatt $\begin{array}{llllllllllllllllllll}A & Q & M & E & \text { L } & Y & N & A & \text { V } & \text { A } & R & \text { D } & \text { S } & \text { G } & \text { Y } & \text { S } & \text { E } & \text { E } & \text { Y } & \text { I }\end{array}$ aaaacgttgatcacagtatgaccctcatctgttctgtagatgaagatggcaaaaaagct $\begin{array}{llllllllllllllllllll}K & N & V & D & H & S & M & T & L & I & C & S & V & D & E & D & G & K & K & A\end{array}$ gaagatgtgtgccgtgagtttttaggtaattggtatgattcatacgtaaatgcaaccaat $\begin{array}{llllllllllllllllllll}E & D & V & C & R & E & F & L & G & N & W & Y & D & S & Y & V & N & A & T & N\end{array}$ atctttagtgaaagtaaccaaactcgtggttatgattatcataaaggtcaatggaaagat $\begin{array}{llllllllllllllllllllll}I & F & S & E & S & N & Q & T & R & G & Y & D & Y & H & K & G & Q & W & K & D\end{array}$ tttgttcttcaaggacatactaataccaaacgtcgtgttgattatagcaacgatctaaac $\begin{array}{llllllllllllllllllll}\text { F } & \text { V } & \text { L } & Q & G & \text { H } & \text { T } & \text { N } & \text { T } & \text { K } & \text { R } & \text { R } & \text { V } & \text { D } & \text { Y } & \text { S } & \text { N } & \text { D } & \text { L } & \text { N }\end{array}$ cctgtaggtacacctgaaaaatgtattgaaattattcagcgtgatattgatgcaacaggt $\begin{array}{llllllllllllllllllllllllllll}P & V & G & T & P & E & K & C & I & E & I & I & Q & R & D & I & D & A & T & G\end{array}$ attactaatattacccttggtttcgaagcaaatggctctgaggaagaaatcattgcctct $\begin{array}{llllllllllllllllllll} & \mathrm{T} & \mathrm{N} & \mathrm{I} & \mathrm{T} & \mathrm{L} & \mathrm{G} & \mathrm{F} & \mathrm{E} & \mathrm{A} & \mathrm{N} & \mathrm{G} & \mathrm{S} & \mathrm{E} & \mathrm{E} & \mathrm{E} & \mathrm{I} & \mathrm{I} & \mathrm{A} & \mathrm{S}\end{array}$ atgaagcgcttcatgacgcaagttgcaccattcttaaaagatccaaaataaataaatcac $\begin{array}{llllllllllllllllllllll}M & K & R & F & M & T & Q & V & A & P & F & \text { L } & K & D & P & K & -\end{array}$

(a) tcagattaactttaataaataatataaggaatataacatgaattttggattattcttcctc $\begin{array}{lllllllll}M & N & F & G & L & F & F & L\end{array}$ aatttcagcctgaaaatacatcgtcagaaacagttttagataatatgatcaatactgtc $\begin{array}{llllllllllllllllllll}N & F & Q & P & E & N & T & S & S & E & T & V & L & D & N & M & I & N & T & V\end{array}$ tctttagttgataaagattataaaactttacaactgctttagtaaacgagcaccatttt $\begin{array}{llllllllllllllllllll}\text { S } & \text { L } & \text { V } & D & \text { K } & \text { D } & Y & K & N & F & \text { T } & \text { T } & \text { A } & \text { L } & \text { V } & \text { N } & \text { E } & \text { H } & \text { H } & \text { F }\end{array}$ tctaaaaatggtattgtcggtgctccgatgacagctgcaagcttcctattaggactaact $\begin{array}{lllllllllllllllllllll}S & K & N & G & I & V & G & A & P & M & T & A & A & S & F & L & L & G & L & T\end{array}$ gaacgtttacatattggttctttaaatcaagtgattacaacgcatcacccggttcgtatt $\begin{array}{llllllllllllllllllll}E & R & L & H & I & G & S & L & N & Q & V & I & T & T & H & H & P & V & R & I\end{array}$ gcagaagaagcaagtttgcttgatcaaatgtcagacagccgctttattctaggtttaagt $\begin{array}{llllllllllllllllllll}A & E & E & A & S & L & L & D & Q & M & S & D & S & R & F & I & L & G & L & S\end{array}$ gattgtgttaatgattttgagatggatttctttaaacgtcaacgtgactcacagcagcta $\begin{array}{llllllllllllllllllll}D & C & V & N & D & F & E & M & D & F & F & K & R & Q & R & D & S & Q & Q & L\end{array}$ caatttgaagcttgctatgacatcattaatgaagctatcacaactaattactgccaagct $\begin{array}{llllllllllllllllllll}Q & F & E & A & C & Y & D & I & I & N & E & A & I & T & T & N & Y & C & Q & A\end{array}$ aataatgatttttataacttccctcgtatctcaattaatcctcattgtttaagcaaagag $\begin{array}{llllllllllllllllllll}N & N & D & F & Y & N & F & P & R & I & S & I & N & P & H & C & L & S & K & E\end{array}$ aatatgaagcaatatattttggcttctagtgtgagtgttgttgagtgggctgctaaaaaa $\begin{array}{llllllllllllllllllll}N & M & K & Q & Y & I & \text { L } & A & \text { S } & \text { S } & \text { V } & \text { S } & \text { V } & \text { V } & \text { E } & \text { W } & \text { A } & \text { A } & \text { K } & \text { K }\end{array}$ gcgcttccactaacatatcgttggagcgatagccttgaagataaagagattctttataag $\begin{array}{llllllllllllllllllll}\text { A } & \text { L } & \text { P } & \text { L } & \text { T } & Y & R & \text { W } & \text { S } & \text { D } & \text { S } & \text { L } & \text { E } & \text { D } & \text { K } & \text { E } & \text { I } & \text { L } & Y & \text { K }\end{array}$ cgttatttagaagttgcagcaaagcataatattgacgtttctaatgtcgagcatcagttc $\begin{array}{llllllllllllllllllll}R & Y & \text { L } & E & \text { V } & \text { A } & \text { A } & \text { K } & H & \text { N } & \text { I } & D & \text { V } & \text { S } & \text { N } & \text { V } & \text { E } & H & Q & F\end{array}$ ccactgcttgtaaatttaaatcatgatcgtgatgttgctcatcaagaagcaacggcctat $\begin{array}{llllllllllllllllllll}\text { P } & \text { L } & \text { L } & \text { V } & \text { N } & \text { L } & \text { N } & \text { H } & \text { D } & \text { R } & \text { D } & \text { V } & \text { A } & \text { H } & \text { Q } & \text { E } & \text { A } & \text { T } & \text { A } & \text { Y }\end{array}$ ttagcaagttatattgctgaagtatacccacatctaaatcagcaacaaaaattgctgaa $\begin{array}{llllllllllllllllllll}\text { L } & A & \text { S } & Y & I & A & E & \text { V } & \text { Y } & \text { P } & \text { H } & \text { L } & \text { N } & Q & Q & Q & K & I & A & E\end{array}$ cttattagccaacatgcgattggtactgataatgattactatgaatcaacattaaatgcg $\begin{array}{lllllllllllllllllllll}\text { L } & I & S & Q & H & A & I & G & T & D & N & D & Y & Y & E & S & T & L & N & A\end{array}$ ttagagcgtacaggctcaaaaaatgtattactttcttttgaatcaatgaagaatcatgat $\begin{array}{lllllllllllllllllllll}\text { L } & E & R & T & G & S & K & N & V & L & L & S & F & E & S & M & K & N & H & D\end{array}$ gatgttgtaaaagtgattaatatgaatgagaagattcaaaagaatttaccaagctcgtaa $\begin{array}{llllllllllllllllllll}\text { D } & \text { V } & \text { V } & \text { K } & \text { V } & \text { I } & \text { N } & \text { M } & \text { N } & \text { E } & \text { K } & \text { I } & Q & \text { K } & \text { N } & \text { L } & P & \text { S } & \text { S } & -\end{array}$

(b)

FIGURE 11: Full length nucleotide and amino acid sequences of luciferase. (a) and (b) sequences indicate nucleotide and amino acid sequence, respectively. The first nucleotide and amino acid of lux A and lux B of Photobacterium sp. strain MIE are underlined.

was found to copper concentrations in the water samples with temporal inhibition to both bacterial assays and elevated copper concentration occurred approximately between 10.00 and 18.00 hours (Figure 12). Heavy metal analysis of the water samples showed that the presence of the heavy metal copper with the highest concentration measured at the same spot was $2.17 \mathrm{mg} / \mathrm{L}$ occurring at 14.00 hour or $2.00 \mathrm{pm}$. The amount of other heavy metals such as mercury, silver, cadmium, and lead was negligible (data not shown).

\section{Discussion}

A luminescent bacterial strain was successfully isolated from the mackerel, Rastrelliger kanagurta. To the best of our knowledge this is the first report on the isolation of bioluminescent bacterium from this species. Several other bioluminescent bacteria for the purpose of bioassay have been reported such as $V$. fischeri [32, 33], V. harveyi [34], V. logei [35], and $V$. fischeri strain DSM 744 [36]. They were all isolated from marine environment with the exception of Photorhabdus luminescens, which was isolated from terrestrial environment [37]. Friedrich and Greenberg [38] reported that growth on carbon source other than glycerol such as glucose elicited catabolite repression of luciferase activity, hence the lag phase

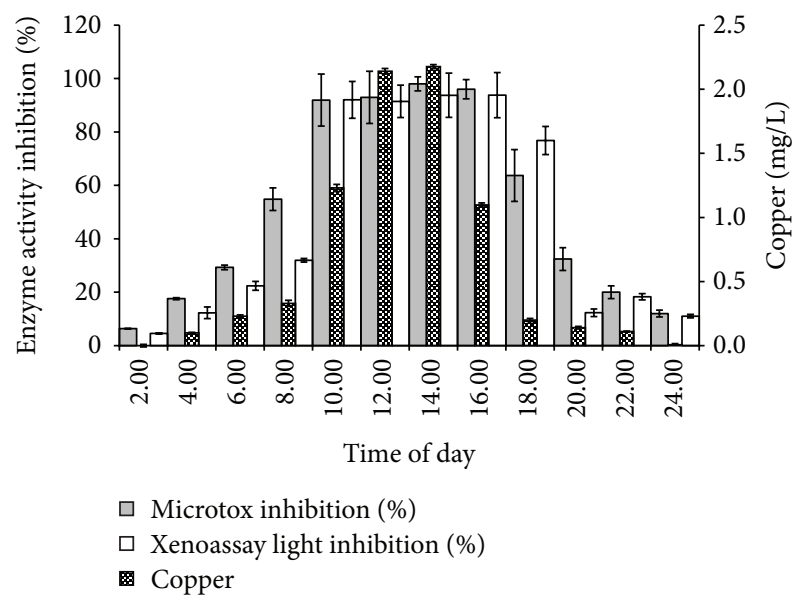

FIGURE 12: Inhibition of bioluminescence activity of Microtox and Xenoassay Light assays and copper concentration in water samples. Data is mean standard error of the mean $(n=3)$.

observed. Based on this study, glycerol was selected as the main carbon source. High luminescence activities have been observed at $3 \mathrm{~g} / \mathrm{L}$ glycerol in both $P$. phosphoreum strain 
NRRL-B 1117 [29] and P. phosphoreum strain ATCC 11040 [39]. Other bioluminescent bacteria, such as $P$. phosphoreum KCTC 2852, were cultivated in luminescence media which contain $10 \mathrm{~g} / \mathrm{L}$ of peptone [40] and $V$. fischeri was grown in seawater media containing $5 \mathrm{~g} / \mathrm{L}$ bacto-tryptone [41]. Sodium ion supports the growth of this marine bacterium because it helps to maintain osmotic pressure. The changes of osmotic pressure will result in cell lysis [42]. In comparison, Photobacterium sp. strain LuB-1 has shown good sensitivity in a wide range of salt concentrations from 0.2 to $5 \%(\mathrm{w} / \mathrm{v})$ [9]. A study by Cook et al. [43] shows that salinity affected greatly bioluminescence emitted by $V$. fischeri and $P$. pseudomonas.

In comparison, stable luminescence activities of $P$. phosphoreum strain KM MGU 331 were observed within the $\mathrm{pH}$ range of 7.0 to 9.0 [44]. Most bioluminescent bacteria require $\mathrm{pH}$ values close to neutral for growth and high luminescence activities [45]. For example, P. phosphoreum strain KCTC 2852 grows at $\mathrm{pH} 7.0$ [40] and the optimum $\mathrm{pH}$ value for both growth and luminescence production of $V$. fischeri is at $\mathrm{pH} 7.5$ [46].

The size of the new luciferase protein (translated) from Photobacterium strain MIE was compared with the previous well-studied luciferase protein from Vibrio harveyi (GenBank Accession no. DQ436496.1) to see any differences based on protein sequence. Although, many successfully isolated luciferases were reported, only the luciferases protein from $V$. harveyi was successfully crystallized so far [47]. Based on Blastp alignment, lux AB from Photobacterium strain MIE only showed $61 \%$ similarity to lux A and $48 \%$ similarity to lux B proteins from $V$. harveyi (result not shown). Since similarity between both luciferases was moderate, it is very interesting to know more about its protein structure and how the newly isolated luciferase could show broad optimal luminescence activity that includes room temperature $\left(25^{\circ} \mathrm{C}-30^{\circ} \mathrm{C}\right)$.

Luminescence at these relatively high temperatures is an advantage especially for near real time biomonitoring system in a tropical country like Malaysia where the temperature is within the range of the bacterial optimal luminescent temperature range. Most of the other commonly studied bioluminescent bacteria have lower temperature for efficient bioassays than strain MIE. For example, Kim et al. [48] reported an optimum temperature of $18^{\circ} \mathrm{C}$ for $P$. phosphoreum strain KCTC 2852 and P. fischeri has an optimum temperature of $15^{\circ} \mathrm{C}$ [49]. The optimum temperature for both $V$. fischeri and $P$. phosphoreum strain $\mathrm{A}-13$ is $15^{\circ} \mathrm{C}[9,50,51]$. In order to maintain stability of the luminescence produced by strain MIE, the bacterial cultures should be harvested between 8 and 24 hours of incubation. This result conforms to the study done by Girotti et al. [14] that shows the relationship between luminescence peak of $V$. logei and its growth curve.

The results demonstrated near real time capability of the proposed system. The concentrations of copper exceeded the maximum permissible limit (MPL) outlined by the DOE Malaysia at $0.02 \mathrm{mg} / \mathrm{L}$ for class II (DOE 2011) [1]. The errors of the inhibition measurement (coefficient of variation) were less than $10 \%(n=5)$ suggesting good reproducibility. Strain MIE exhibited high tolerance when subjected to a wide range of environmental factors. This is essential as the application of the bioluminescent assay in various samples requires a luminescent strain with better sensitivity and stability in diverse assay conditions. This work shows that strain MIE is also capable of producing significant luminescence at slightly acidic environment. The bioluminescence process, as well as growth, can be suppressed at certain $\mathrm{pHs}$ due to the inhibition of enzymes involved in the bacterial metabolic reactions and the instability of the transport protein [52]. In this case, a wide range of $\mathrm{pHs}$ for luminescence is a strong advantage for water monitoring, especially in heavy metal contaminated sites, as deviation in sample pHs can be highly tolerated by this strain.

A field trial performed in an industrial site that channels its waters into agricultural areas in Penang showed the practicality of this strain for water quality biomonitoring in the tropical region. Simple methodology, rapid assay time, and reproducible data are major advantages in any field assessment. The fluctuation and variation in water temperature can change the metabolic response of the strain used in the assay and greatly affect the luminescence production [13]. Other bioluminescent bacteria such as V. fischeri and $P$. phosphoreum have optimum temperatures at $15^{\circ} \mathrm{C}$ [53]. These bacteria are not suitable for real time monitoring studies in tropical areas which can generally have temperature of more than $15^{\circ} \mathrm{C}$. Any assays utilizing these bacteria under tropical conditions can be costly due to the requirement of expensive refrigeration or incubation. Our works show that this strain performed successfully at ambient temperature. Furthermore, the toxicity assay on copper-contaminated water was also demonstrated to be fast and precise. Bioassay using this strain has the potential to be cheaper, faster, and more stable than other classical toxicity bioassays. This proposed luminescence system should be able to address problems and issues related to a large scale biomonitoring of toxicants in rivers basins that fed into agricultural areas $[54,55]$.

Future works include the determination of half maximal inhibitory concentration $\left(\mathrm{IC}_{50}\right)$ of selected heavy metals, pesticides, and other xenobiotics to the bioluminescence system and a large scale field trial work assessment of the proposed system in comparison with ToxAlert, a near real time system, and the classical Microtox, which are all based on $V$. fischeri.

\section{Conflict of Interests}

The authors declare that there is no conflict of interests regarding the publication of this paper.

\section{Acknowledgment}

This work was supported by the research grant from the Ministry of Science, Technology and Innovation (MOSTI) under the Science Fund Grant nos. 02-01-04-SF0445 and 0201-04-SF0445. 


\section{References}

[1] DOE, "Malaysia environmental quality report," Tech. Rep. 0127-6433, Department of Environment, Ministry of Natural Resources and Environment Malaysia, 2011.

[2] P.-G. Rieger, H.-M. Meier, M. Gerle, U. Vogt, T. Groth, and H.-J. Knackmuss, "Xenobiotics in the environment: present and future strategies to obviate the problem of biological persistence," Journal of Biotechnology, vol. 94, no. 1, pp. 101-123, 2002.

[3] N. Z. Jovanovic, "The use of treated effluent for agricultural irrigation: current status in the Bottelary catchment (South Africa)," Ecology Environment, vol. 112, pp. 371-380, 2008.

[4] Y. Shukor, N. A. Baharom, F. A. Rahman, M. P. Abdullah, N. A. Shamaan, and M. A. Syed, "Development of a heavy metals enzymatic-based assay using papain," Analytica Chimica Acta, vol. 566, no. 2, pp. 283-289, 2006.

[5] D. L. Isenberg and A. Bulich, "Environmental monitoring: use of luminescent bacteria," in Chemical Safety: International Reference Manual, M. Richardson, Ed., VCH Verlagsgesellschaft $\mathrm{mbH}$, Weinheim, Germany, 2007.

[6] USEPA, "Whole effluent toxicity alternate test proceduremicrotox. Guidelines establishing test procedures for the analysis of pollutants under the clean water act," National Primary Drinking Water Regulations; and National Secondary Drinking Water Regulations; Analysis and Sampling Procedures; Proposed Rule 69, United States Environmental Protection Agency (USEPA), Washington, Wash, USA, 2004.

[7] S. Girotti, E. N. Ferri, M. G. Fumo, and E. Maiolini, "Monitoring of environmental pollutants by bioluminescent bacteria," Analytica Chimica Acta, vol. 608, no. 1, pp. 2-29, 2008.

[8] E. A. Meighen, "Enzymes and genes from the lux operons of bioluminescent bacteria," Annual Review of Microbiology, vol. 42, pp. 151-176, 1988.

[9] Y. Hong, Z. Chen, B. Zhang, and Q. Zhai, "Isolation of Photobacterium sp. LuB-1 and its application in rapid assays for chemical toxicants in water," Letters in Applied Microbiology, vol. 51, no. 3, pp. 308-312, 2010.

[10] A. A. Bulich and D. L. Isenberg, "Use of the luminescent bacterial system for the rapid assessment of aquatic toxicity," ISA Transactions, vol. 20, no. 1, pp. 29-33, 1981.

[11] M. Warne, E. Boyd, A. Meharg et al., "Quantitative structuretoxicity relationships for halobenzenes in two species of bioluminescent bacteria, Pseudomonas fluorescens and Vibrio fischeri, using an atom-centered semi-empirical molecular-orbital based model," SAR QSAR Environmental Research, vol. 10, pp. 17-38, 1999.

[12] B. T. Johnson, "Microtox acute toxicity test," in Small-Scale Freshwater Toxicity Investigations, C. Blaise and J.-F. Férard, Eds., pp. 69-105, Springer, Dordrecht, The Netherlands, 2005.

[13] R. E. Dewhurst, J. R. Wheeler, K. S. Chummun, J. D. Mather, A. Callaghan, and M. Crane, "The comparison of rapid bioassays for the assessment of urban groundwater quality," Chemosphere, vol. 47, no. 5, pp. 547-554, 2002.

[14] S. Girotti, L. Bolelli, A. Roda, G. Gentilomi, and M. Musiani, "Improved detection of toxic chemicals using bioluminescent bacteria," Analytica Chimica Acta, vol. 471, no. 1, pp. 113-120, 2002.

[15] S. Lee and B. Pradhan, "Landslide hazard mapping at Selangor, Malaysia using frequency ratio and logistic regression models," Landslides, vol. 4, no. 1, pp. 33-41, 2007.
[16] H.-H. Chiu, H.-H. Chou, W.-D. Jean, and W.-Y. Shieh, "Isolation and characterization of marine luminous bacteria from shallow coastal waters of Taiwan," Journal of Microbiology, Immunology and Infection, vol. 40, no. 1, pp. 14-23, 2007.

[17] N. Makiguchi, M. Arita, and Y. Asai, "Isolation, identification, and several characteristics of luminous bacteria," Journal of General and Applied Microbiology, vol. 25, no. 6, pp. 387-396, 1979.

[18] R. V. Miller and M. J. Day, Microbial Evolution: Gene Establishment, Survival, and Exchange, ASM Press, Washington, Wash, USA, 2004.

[19] M. A. Larkin, G. Blackshields, N. P. Brown et al., "Clustal W and clustal X version 2.0," Bioinformatics, vol. 23, no. 21, pp. 29472948, 2007.

[20] G. Holmquist, M. Gray, T. Porter, and J. Jordan, "Characterization of Giemsa dark- and light-band DNA," Cell, vol. 31, no. 1, pp. 121-129, 1982.

[21] M. Kimura, "A simple method for estimating evolutionary rates of base substitutions through comparative studies of nucleotide sequences," Journal of Molecular Evolution, vol. 16, no. 2, pp. 111120,1980

[22] J. Felsenstein, "Estimating effective population size from samples of sequences: a bootstrap Monte Carlo integration method," Genetical Research, vol. 60, no. 3, pp. 209-220, 1992.

[23] H. Kishino and M. Hasegawa, "Evaluation of the maximum likelihood estimate of the evolutionary tree topologies from DNA sequence data, and the branching order in hominoide," Journal of Molecular Evolution, vol. 29, no. 2, pp. 170-179, 1989.

[24] P. J. Lockhart, M. A. Steel, M. D. Hendy, and D. Penny, "Recovering evolutionary trees under a more realistic model of sequence evolution," Molecular Biology and Evolution, vol. 11, no. 4, pp. 605-612, 1994.

[25] N. Saitou and M. Nei, "The neighbor-joining method: a new method for reconstructing phylogenetic trees," Molecular biology and evolution, vol. 4, no. 4, pp. 406-425, 1987.

[26] J. Felsenstein, "Confidence limits on phylogenies: an approach using the bootstrap," Evolution, vol. 39, pp. 783-791, 1985.

[27] R. D.m.page, “TreeView: An application to display phylogenetic trees on personal computers," Computer Applications in the Biosciences, vol. 12, no. 4, pp. 357-358, 1996.

[28] S. Scheerer, F. Gomez, and D. Lloyd, "Bioluminescence of Vibrio fischeri in continuous culture: optimal conditions for stability and intensity of photoemission," Journal of Microbiological Methods, vol. 67, no. 2, pp. 321-329, 2006.

[29] U.-H. Chun, N. Simonov, Y. Chen, and M. L. Britz, "Continuous pollution monitoring using Photobacterium phosphoreum," Resources, Conservation and Recycling, vol. 18, no. 1-4, pp. 2540, 1996.

[30] M. Y. Shukor, N. Masdor, N. A. Baharom et al., "An inhibitive determination method for heavy metals using bromelain, a cysteine protease," Applied Biochemistry and Biotechnology, vol. 144, no. 3, pp. 283-291, 2008.

[31] F. Conforti, G. Ioele, G. A. Statti, M. Marrelli, G. Ragno, and F. Menichini, "Antiproliferative activity against human tumor cell lines and toxicity test on Mediterranean dietary plants," Food and Chemical Toxicology, vol. 46, no. 10, pp. 3325-3332, 2008.

[32] E. G. Ruby, "Lessons from a cooperative, bacterial-animal association: the Vibrio fischeri-Euprymna scolopes light organ symbiosis," Annual Review of Microbiology, vol. 50, pp. 591-624, 1996. 
[33] E. G. Ruby and K.-H. Lee, "The Vibrio fischeri-Euprymna scolopes light organ association: current ecological paradigms," Applied and Environmental Microbiology, vol. 64, no. 3, pp. 805812, 1998.

[34] J. L. Reichelt and P. Baumann, "Taxonomy of the marine, luminous bacteria," Archives Microbiology, vol. 94, no. 4, pp. 283-330, 1973.

[35] S. S. Bang, P. Baumann, and K. H. Nealson, "Phenotypic characterization of Photobacterium logei (sp. nov.), a species related to P. fischeri," Current Microbiology, vol. 1, no. 5, pp. 285288, 1978.

[36] H. Attar and S. Afshar, "Design of sensible biosensor for rapid detection of biocides in potable water," Asian Journal of Biotechnology, vol. 2, pp. 120-126, 2010.

[37] N. E. Boemare, R. J. Akhurst, and R. G. Mourant, "DNA relatedness between Xenorhabdus spp. (Enterobacteriaceae), symbiotic bacteria of entomopathogenic nematodes, and a proposal to transfer Xenorhabdus luminescens to a new genus, Photorhabdus gen. nov," International Journal of Systematic Bacteriology, vol. 43, no. 2, pp. 249-255, 1993.

[38] W. F. Friedrich and E. P. Greenberg, "Glucose repression of luminescence and luciferase in Vibrio fischeri," Archives of Microbiology, vol. 134, no. 2, pp. 87-91, 1983.

[39] A. E. Ronco, "Development of a bioassay reagent using Photobacterium phosphoreum as a test for the detection of aquatic toxicants," World Journal of Microbiology \& Biotechnology, vol. 8, no. 3, pp. 316-318, 1992.

[40] S. H. A. Hassan and S. E. Oh, "Improved detection of toxic chemicals by Photobacterium phosphoreum using modified Boss medium," Journal of Photochemistry and Photobiology B: Biology, vol. 101, no. 1, pp. 16-21, 2010.

[41] E. G. Ruby and L. M. Asato, "Growth and flagellation of Vibrio fischeri during initiation of the sepiolid squid light organ symbiosis," Archives of Microbiology, vol. 159, no. 2, pp. 160-167, 1993.

[42] F. Onorati and M. Mecozzi, "Effects of two diluents in the Microtox toxicity bioassay with marine sediments," Chemosphere, vol. 54, no. 5, pp. 679-687, 2004.

[43] S. V. Cook, A. Chu, and R. H. Goodman, "Influence of salinity on Vibrio fischeri and lux-modified Pseudomonas fluorescens toxicity bioassays," Environmental Toxicology and Chemistry, vol. 19, no. 10, pp. 2474-2477, 2000.

[44] V. V. Kuts and A. D. Ismailov, "Physiological and emission characteristics of the luminescent bacterium Photobacterium phosphoreum from the White Sea," Microbiology, vol. 78, no. 5, pp. 554-558, 2009.

[45] J. Farmer and F. Hickman-Brenner, "The genera Vibrio and Photobacterium," in The Prokaryote, vol. 2, pp. 2952-3011, 1992.

[46] W. Soto, J. Gutierrez, M. D. Remmenga, and M. K. Nishiguchi, "Salinity and temperature effects on physiological responses of Vibrio fischeri from diverse ecological niches," Microbial Ecology, vol. 57, no. 1, pp. 140-150, 2009.

[47] A. J. Fisher, "Three-dimensional structure of bacterial luciferase from Vibrio harveyi at $2.4 \AA$ resolution 1,2, Biochemistry, vol. 34, no. 20, pp. 6581-6586, 1995.

[48] S. K. Kim, B. S. Lee, J. G. Lee, H. J. Seo, and E. K. Kim, "Continuous water toxicity monitoring using immobilized Photobacterium phosphoreum," Biotechnology and Bioprocess Engineering, vol. 8, no. 2, pp. 147-150, 2003.

[49] J. C. Makemson, "Control of in vivo luminescence in psychrophilic marine Photobacterium," Archieces Microbiology, vol. 93, no. 4, pp. 347-358, 1973.
[50] W. E. Miller, S. A. Peterson, J. C. Greene, and C. A. Callahan, "Comparative toxicology of laboratory organisms for assessing hazardous waste sites," Journal of Environmental Quality, vol. 14, no. 4, pp. 569-574, 1985.

[51] K. W. Thomulka, D. J. McGee, and J. H. Lange, "Use of the bioluminescent bacterium Photobacterium phosphoreum to detect potentially biohazardous materials in water," Bulletin of Environmental Contamination and Toxicology, vol. 51, no. 4, pp. 538-544, 1993.

[52] I. R. Booth, "Regulation of cytoplasmic pH in bacteria," Microbiological Reviews, vol. 49, no. 4, pp. 359-378, 1985.

[53] D. T. Pooley, J. Larsson, G. Jones et al., "Continuous culture of Photobacterium," Biosensors and Bioelectronics, vol. 19, no. 11, pp. 1457-1463, 2004.

[54] J. D. Oster and S. R. Grattan, "Drainage water reuse," Irrigation and Drainage Systems, vol. 16, no. 4, pp. 297-310, 2002.

[55] N. Mathur, P. Bhatnagar, and P. Bakre, "Use of Salmonella/microsome reversion bioassay for monitoring industrial wastewater treatment plants in Rajasthan, India," Journal of Environment Biology, vol. 33, pp. 531-537, 2012. 

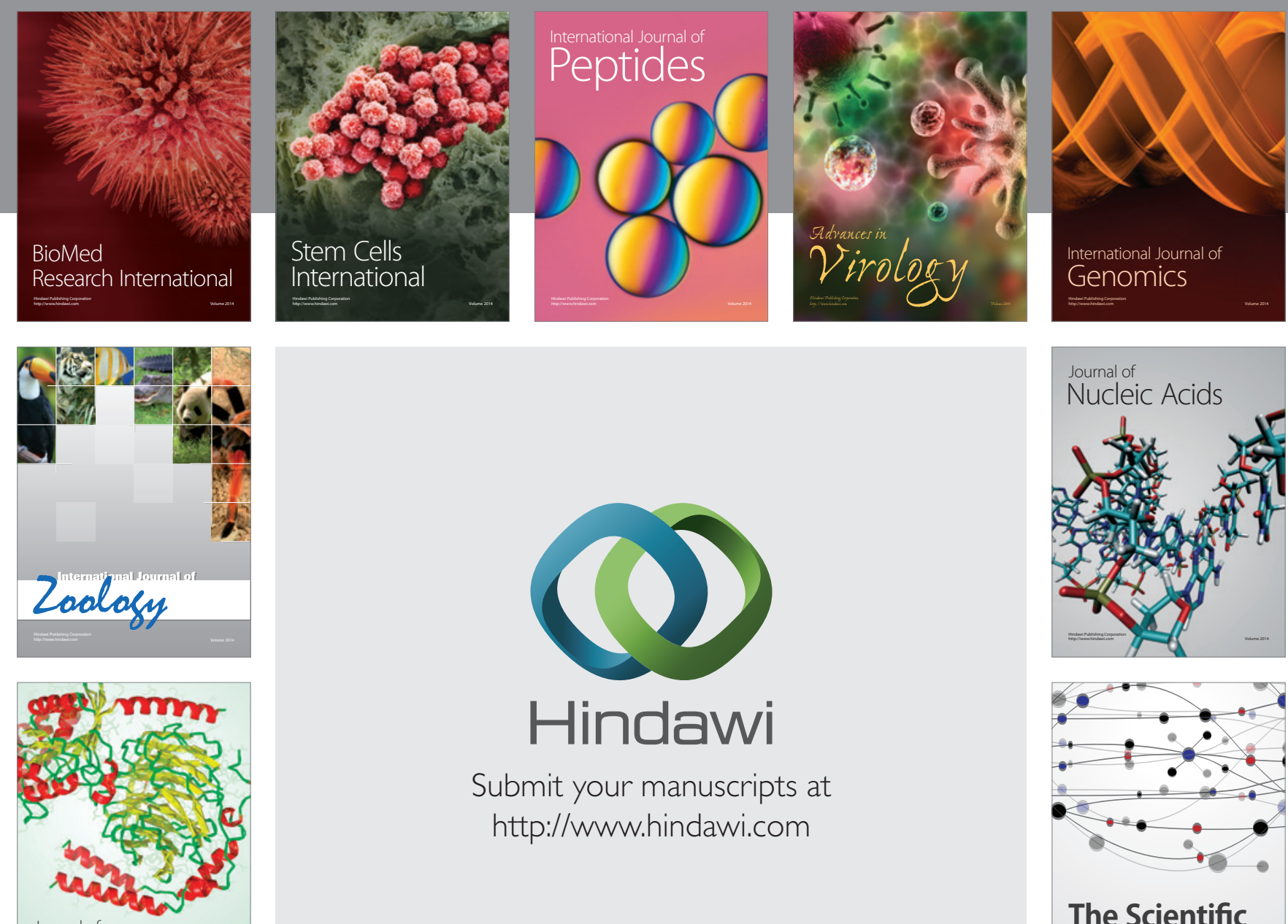

Submit your manuscripts at

http://www.hindawi.com

Journal of
Signal Transduction
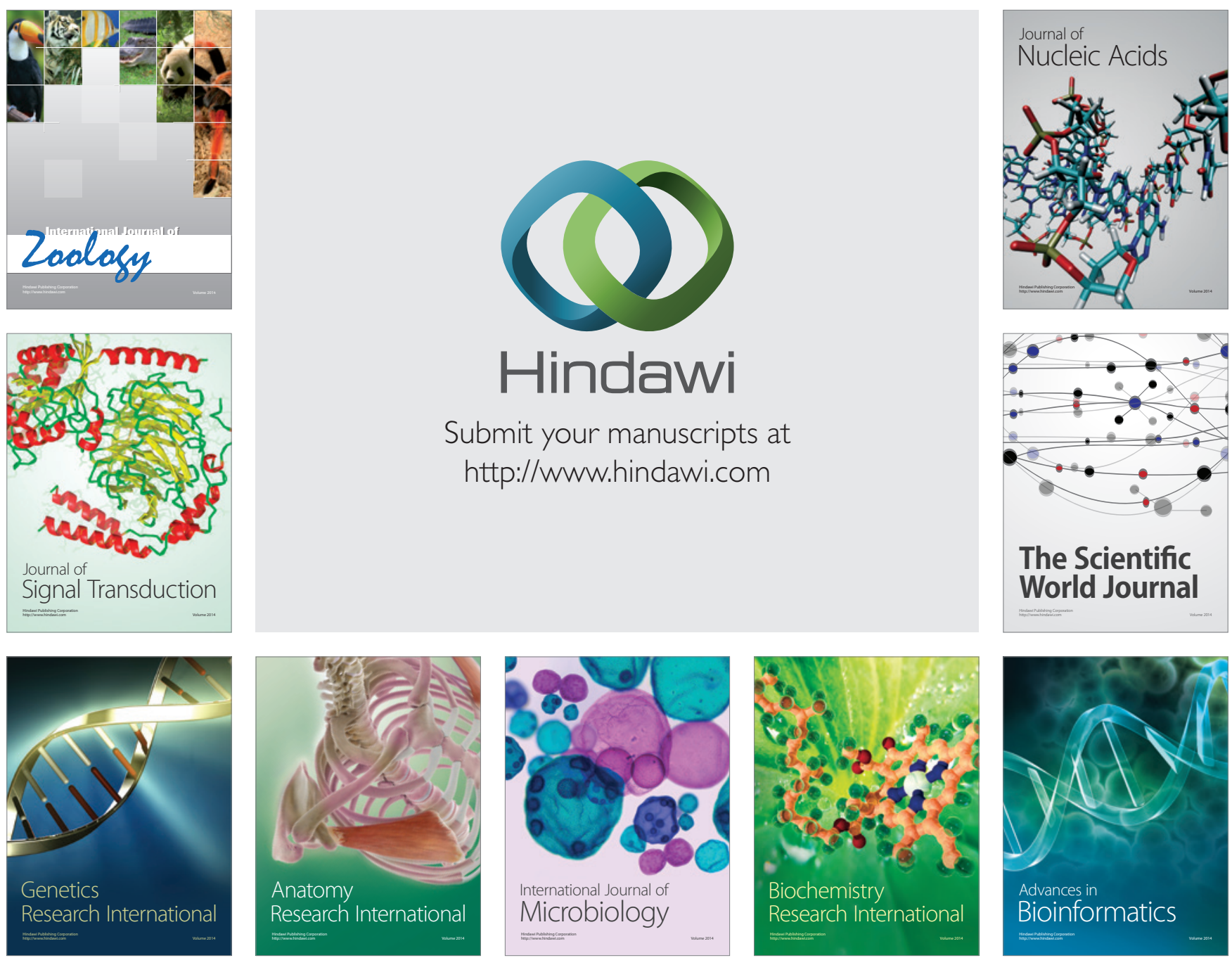

The Scientific World Journal
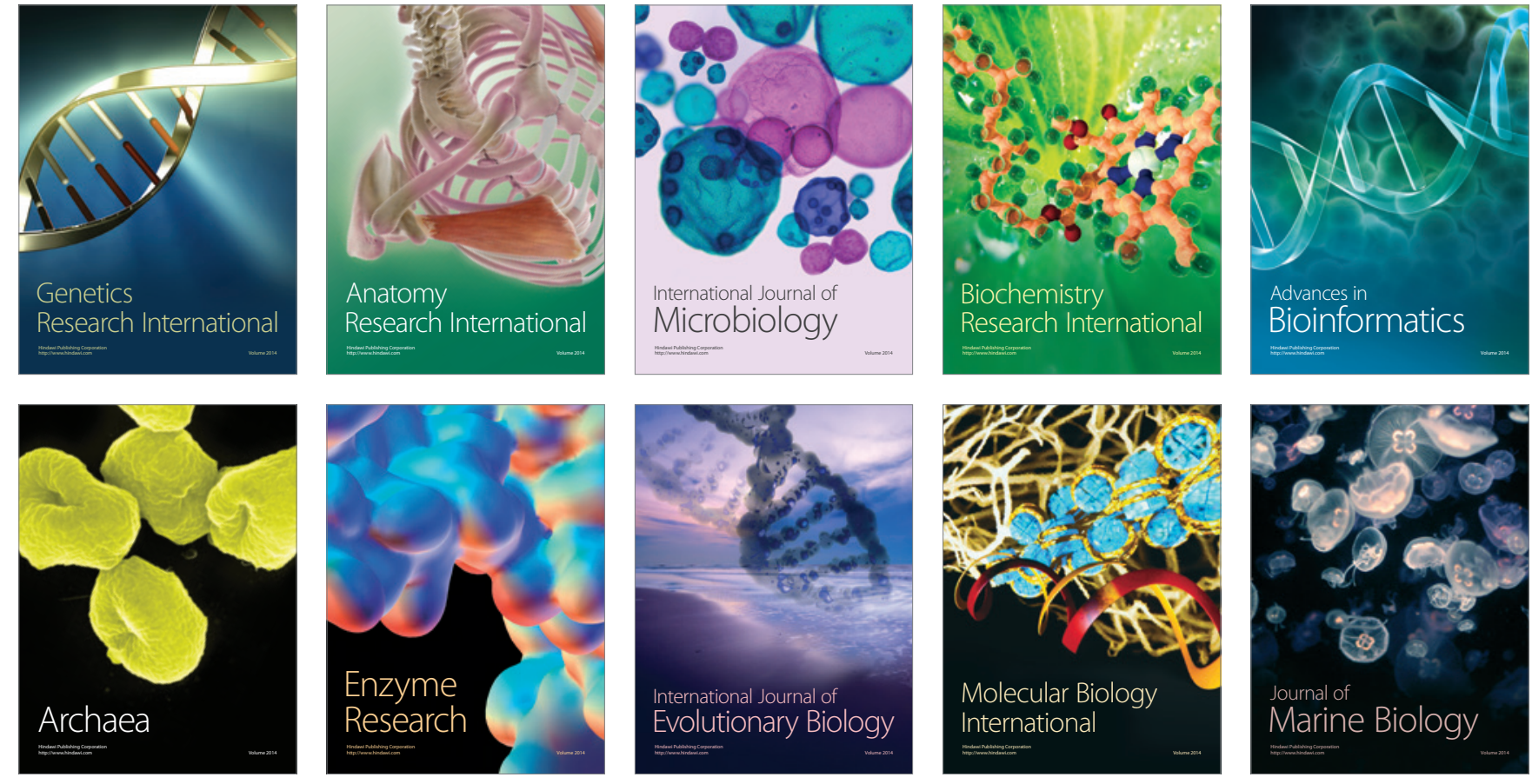